計を送付して，データを算出していただいた。

【結果】ガラス線量計の線量報告デー夕は個人線量当量 $(\mathrm{H} 10 \mathrm{~cm}, \mathrm{H}$ $70 \mu \mathrm{m})$ であり, OSL線量計に関しては, 吸収線量 $(\mathrm{Gy})$ でも算出さ れ，マニュアルに沿った換算であった．線量計の向きによる違い は, 線質が変化しても大きな変化は認められなかったが, エネル ギー表示において，アクリルに比べ水ファントムでOSL線量計の䛊 差が最大で50\%あった。電離箱線量計との比較では, ガラス, OSL 共に若干低い值を示した。

【結語】今後の課題として, 線量換算, 水ファントムに関しては規格 精度が上げられる. 今後, 課題を検討していくことにより, 簡便で 安価な線量測定が線量計等を所持していない施設においても可能に なると考える。

72 イメージングプレートによるIVR時の患者被曝線量測定 1 報 測定レンジの拡大

山形大学医学部附属病院 - 放射線部 佐藤俊光, 江口陽一, 石井英夫 高橋和榮

東北大学大学院 $\cdot$ 薬学研究科 大内浩子

富士写真フイルム(株) 森 啓司

【目的】IVR時の患者被曝線量を測定する方法として, 低感度X線フィ ルム等による2次元分布法がある.この方法のメリットとして広範 囲の線量測定が可能であること, 最も被曝した部位がほぼ特定でき ることなどがある. IVR術後の被曝管理として重要なことは, どの 部位にどれだけの被曝をしたかを知ることであるため，この 2 次元 分布法は有効である. しかし, 線量の測定レンジの問題や再利用が できないというデメリットがある。再利用が可能な媒体としてIP(イ メージングプレート)がある. 今回はIPにて, 被曝線量測定レンジの 拡大を中心に検討し, IVR時の患者被曝線量測定への可能性を検討 した。

【使用機器】IPはBAS-TR, BAS-MS(富士写真フイルム), 読取装置は BAS-1000(富士写真フイルム)である.

【方法】線量測定レンジ拡大のため，1ＩＩ読取時においてIP表面を色 セロファンで覆い, 励起光および読取装置の光電子增倍管へ入射す る輝尽発光を減弱させた (以下, 七ロファン法). 2. X線照射後, ア ニーリング $\left(80^{\circ}, 100^{\circ}, 120^{\circ}\right)$ を行い, フェーディングの影響を最小 にしつつ, 輝尽発光を減弱させた(以下, アニーリング法).

【結果】BAS-TRを用いたセロファン法では, 赤と青のセロファンの 組合せにより100Gyまで，アニーリング法では10Gy以上測定可能で あった. よって, IVR時の患者被曝線量測定には充分な測定レンジ を有しており，再利用も可能なことから実用的な測定方法になりう ることが示唆された.

73 反射型フィルムによる心臓カテーテル診療時の患者被ばくに ついて

新潟大学医歯学総合病院·放射線部門 吉村秀太郎，岡 哲也 布施真至, 坂井裕則, 能登義幸、上田弘之

(有)アールテック 宮沢正則

【目的】心臓カテーテル診療時, 特に冠動脈疾患における臨床時での 患者被ばくの実測線量の把握は難しいと言われている，その主因は 心臟カテーテル診療時でのX線入射のアプローチ角度が多岐にわた り患者皮膚面での最多ポイント(ホットスポット)が定まらず実測し にくいなどが上げられる，今回，私達はフィルム法により正確な ホットスポットを見極め, その実測線量も把握可能となったので報 告する.

【方法】測定には反射型フィルム(GAFCHROMIC-Film XR Type-R)の 半切サイズを患者背面 (X線入射方向) に密着し, 全国の心臓カテー テル診療の施行施設の協力を得て, 患者111名(58施設)のPCIを中心 に右・左冠動脈に㧍ける臨床診療時のホットスポットの分析とその
線量を測定し，併せて被ばく因子である透視時間，撮影回数そして 撮影フレーム数との関係も検討した.

【結果】臨床時の診療内容を(1)ルーチン検査(診断のみ)(2)PCIと診断 (3)PCIのみの3つに区分し, 各々の症例患者数(人), 患者皮成被ば く線量 (cGy), そして被ばく因子としての透視時間(分), 撮影回数 (回), 撮影総フレーム数(f)の項目について検討した，それらの3つ の実測結果の平均值は次のようになった（1)では 15 人， $72 \mathrm{cGy}, 13$ 分，12回，1,508f，(2)では29人，246cGy，31分，33回，2,701f，(3) では67人，167cGy，26分，24回，1,468fとなった。また，ホットス ポットや左右冠動脈別の分類, 分析等の詳細は当日報告する。な お，この報告の一部に関しては全国循環器撮影研究会の協力と厚生 労働省の医薬安全総合研究事業における厚生科学研究補助金の助成 によるものである.

74 面積線量計を用いた術者被曝線量推定に関する検討(第 2 報 臨床応用)

山梨大学医学部附属病院・放射線部 坂本 竍，小林 寬，弓削 誠 相川良人，吉澤和弥，秋山三郎，佐野芳知

【目的】IVRが進歩発展し, 複雑な手技や件数の増加にともない術者 被曝の管理が重要になっている，そこで，面積線量計を用い手技中 の術者被曝線量が推定可能であるかを第60回総会において報告し た．今回は，面積線量と術者の被曝線量の関係を臨床に対応出来る ように検討した。

【方法】術者の実測して得られた各部位での被曝線量と面積線量およ び透視時間との関係について比較した，対象は心血管検查時での術 者であり, 穿刺部位 (大腿動脈・橈骨動脈), 防護板 (使用時・未使用 時)による影響について調べた。なお，術者被曝線量は 1 症例ごと に雨手指, 両手, 両肩, 頸部, 防護衣内側胸部にTLD を装着し測定 した.

【結果 · 考察】心血管検查時の術者被曝において実効線量, 左有・頸 部の等価線量と面積線量の関係は強い相関が得られた。穿刺部位に おいては大腿動脈部での相関が橈骨動脈部での相関より高く，バラ ツキも少ない結果となった。防護板の影響は，未使用時において実 測值と面積線量值・透視時間ともに相関が良く, 使用時は相関が下 がる結果となった，両手指の等価線量では実測值と面積線量の関係 が透視時間との関係より相関は良い結果となったが, 他の部位に比 較すると相関は低い結果となった，今回の検討より穿刺部位，防護 板を考慮することにより, 面積線量から術者線量の推定精度が向上 することが示唆された。術者被曝線量は実測することが原則である が, 測定が困難な場合等は面積線量を用いることにより推定するこ とが可能であると考える.

\section{5 脳動脈嘼患者に対するIVR時の被ばく線量測定}

東京慈恵会医科大学附属病院·放射線部庄司友和，山下慎一 平松雅樹, 羽染秀樹, 春原信雄、矢本俊一

【目的】当院では脳動脈瘤患者に対するCoil Embolizationが第一選択と なってきている，そのため対象となる動脈瘤は殆んどであり, 部位 や大きさ等により検查時間, 透視時間, ショット数, 患者被ばく線 量も様々である. 残念ながら現在まで放射線障害が 2 例報告されて おり，被ばく管理に対する我々放射線技師の役割は非常に大きいと いえる.そこで今回, 実際にIVR時の患者被ばく線量を把握するた めに, 各測定器を用いた一検査当たりの総吸収線量とホットスポッ トの吸収線量を測定し, 前回の第60回総会で報告した面積線量計を 用いた方法との相関性を求めることを目的とする.

【実験方法】まず，当院における脳動脈瘤患者約50例(H16．5月現在） の部位・大きさ・ネックの方向・アプローチアングル・IVRの手技 に対して調查を行い，最も平均的な手技を導き出し，それらに対し 測定実験を行うこととした。測定器にはガラスバッジ， 